\title{
Girls in the New Media Landscape
}

\author{
Birgitte Tufte
}

No matter where they live, Denmark, Spain, the USA, wherever, young people turn to the new media and communications culture with the same curiosity, enthusiasm and will to master the technology. The culture of children and young people is truly global when it comes to the media; and - given access - we find by and large the same patterns among young people the world over.

From at least this one point of view, the picture is relatively uniform, but there are also a great number of nuances based on geography and economics, differences depending on whether the child lives in a country rich in media and having a high level of media and communications technology - or perhaps the opposite. There are social differences, as well, based on the family's level of education and income, there are age-based differences, and, not least, we find differences between how boys and girls, respectively, use the media they have access to.

In a recently completed five-year study of boys' and girls' everyday activities and media culture1, we - a team of five researchers at the Royal Danish School of Educational Studies - collected both quantitative and qualitative data through a questionnaire survey, observations, interviews with the 120 young people and their teachers, as well as written material (essays, etc.) and drawings.

The part of the study I have been most closely involved in is a qualitative study of twelve families spanning 30 months. Ole Christensen and I were jointly responsible for this part of the project. In order to gain insight into how the media fit into the lives of children and adults, both the lives of individual family members and as part of the families' routines and rituals, we visited the families from time to time over the course of the thirty months.

Children's Culture Network, The Royal Danish School of Educational Studies, Emdrupvej 101, DK-2400 KøbenhavnNV,tufte@dlh.dk
Our findings were reported in a book entitled The changing family: media in the lives of Danish families (Christensen \& Tufte 2001).

In the study we tried to include all the family members, but we were, of course, particularly interested in the child that was our link with the family. All in all we studied 57 people, young and old, paying special attention to the dynamics operating within the family circle and to the media as part of that dynamics. The families were selected so as to result in a sample having the following characteristics: an equal number of girls and boys and both children having a richly varied media consumption and children having a more singular orientation to one or another medium. As it turned out, these criteria produced a sample of families that represented a broad spectrum in terms of education, income, opinion and values. When we started the study in 1998, we operated with two age-groups, 8-year-olds and 12-years-olds; at the end of the study in 2001, the groups were 10-11 and 14-15 years old.

Over the course of the study some new media equipment entered into the picture, but perhaps not as much as might be assumed. Even at the time of our first visit in 1998, it was not uncommon to find as many as four television sets, two VCRs, one or two computers, several stereos and a cell phone in a household. Two-and-a-half years later, one or another TV set has been traded for a larger model, a few families have got Internet access, several households have acquired play stations, some of the elder children have got a TV set and/or a computer in their own room, and cell phones have proliferated. But, all in all, the pace of change has been much more modest than the scenarios sketched by spokespersons for the media hardware and IT branches.

One important finding is that among media television remains the prime mover in families' everyday lives. This is in keeping with the findings of 
other contemporary studies (Livingstone \& Bovill 2001, Drotner 2001). The dominance of television, even if it is highly seasonal, is also confirmed in our conversation with one of our informants, a 9-yearold girl. When asked what she spends most of her time doing, she replied:

Watching TV. But not in the summertime then I like to go out and play, but in the winter I watch TV a lot.

The media play different roles in families' lives, they are used differently and serve different functions: they may be used singly or in concert, i.e., primary use - the user pays attention to content of his or her choosing - or use as a background, where the media break the silence or form a backdrop to other, unrelated activities.

We found that combined use of several media is very common among the families we studied. We also noted frequent shifts between primary and background use. There are of course differences between families, between situations and between media. But on the whole, we can make the following general observations:

- Media and communications equipment are an integral part of the families' everyday lives. Use of this equipment is in many cases 'invisible' in the sense that it is part of the daily routine or ritual rather than a deliberate activity.

- In some families electronic media are a topic of conversation or a forum for interaction between children and adults, whereas in others they are just another feature of day-to-day life, undeserving of comment.

- Television is the medium that occupies the most central role in family life. How people use television is a key to how they go about their lives, day to day.

- The presence of several TV sets in the household leads to individualized viewing and disperses the family members. This is particularly evident when the children enter puberty.

- Radio does not play any major role in the households, albeit children do listen to music on the radio.

- On the one hand, we found that Internet access changes patterns of interaction and activity in the family; it also alters the relations between generations. On the other hand, Internet access is also a frequent source of friction between family members.
- Cell phones are largely a younger generation's medium. Use of cell phones is an expression of a new culture of conversation. (Christensen \& Tufte 2001)

\section{Style, Taste and Gender}

Previous research has documented gender-based differences in use of the media. As a consequence, one of the assumptions in the present study was that many of the children's leisure activities might fall into the categories of "girl things" or "boy things". Not least media producers, marketers and advertisers recognize that girls and boys have different preferences and have been quick to capitalize on those differences. In television advertising, for example, pink ruffles and sugar-sweet girls' voices speak to girls, and action film-like scenes accompanied by deep, manly voices speak to boys. Gendersegregating children's cultures like these stand in stark contrast to the official ideology in the schools and society at large that explicitly tries to counteract these kinds of stereotypes.

The gender perspective is one of the foci of the project. We have sought to identify the ways in which patterns of media use and the subcultures associated with them relate to the children's search for a gender identity and the ambiguities and ambivalence vis-à-vis traditional roles that many children experience.

One thing that strikes anyone who takes an interest in children's everyday lives is the contrast between girls' and boys' bedrooms.

Boys' rooms tend to have more electronic hardware such as TV, video and PCs, whereas girls' rooms are more elaborately decorated and emphasize comfort. This apparently has to do with the "best friend culture" that girls tend to engage in, where two girls sit together in the privacy of their room and talk, hours on end. In this culture, the character of the room is important. Boys, on the other hand, are more oriented toward exploring new technology; when they seek out company, it is often in groups.

As mentioned above, there are some general differences between boys and girls when it comes to their use of mass media, with regard to both the media they use and their preferences regarding media content. Boys watch television somewhat more than girls do; girls read more. In the case of PCs, we find that boys tend to play computer games more than girls, whereas girls - if they use computers and have Internet access - use their computers to chat. Girls listen to music more than boys do. When it 
comes to content and genre preferences, girls prefer films about relationships (romance), whereas boys are more attracted to thrillers and action-adventure. These patterns apply to both television and computer use, as Kirsten Drotner observes in her most recent study (Drotner 2001), which contains the following observations:

- Of all 9- to 16-year-olds, boys devote nearly four times as much time to computer games as girls do, viz., 78 minutes a day as opposed to girls' 18 minutes ... (Drotner 2001:19).

- Girls use the Net more for surfing, chat, e-mail than boys do, whereas boys use the Net more for downloading software, participation in news groups, information searches, home-page production (Drotner 2001:20).

Both similarities and differences are noted in the case of genre preferences:

- Comedy, news, horror and crime adventure are widely popular among both sexes.

- The greatest contrast is noted with regard to romance; 10 per cent of the girls, against 1 per cent of the boys, give romance priority.

- Athletics interests 35 per cent of the boys, against 18 per cent of the girls.

- Action interests 10 per cent of the boys, against 2 per cent of the girls. (Drotner 2001:22)

Music plays an important role in the children's lives. They buy CDs, download music from the Net and keep abreast of "the latest" and who is at the top of the charts.

Even very young girls know quite a lot about various groups, both their music and band members - not least their love life, income, lifestyle, etc. Boys are more singularly focused on the music.

We find age-based differences in music tastes; these are especially pronounced among the girls in our study. Eight- to ten-year-olds prefer to listen to girl groups, whereas an interest in boy bands awakens as they approach puberty. One 13-year-old respondent put it like this:

I have a Britney Spears CD, too, but I don't listen to it very often. I mostly listen to boy bands ... Britney's a bitch. When you're younger you listen to girl groups, but when you get a little older, you listen more to boy bands, both because they're cool and because they say things like, "Oh, how I love you..." and like that.
In the light of these gender-specific differences in media use and preferences it is interesting to find out how girls and boys perceive the possible 'role models' they encounter on the television screen. This is a subject that Danish researcher Anna Eriksen-Terzian, who resides in France, has explored.

Some years ago, she studied perceptions of 'personalities' from the world of television among 7- to 18-year-olds in France. The object of her study was to find out which programmes were most popular among boys and girls, and particularly to find out which figures among all those available to them on the television screen the young people chose as their role models. Eriksen-Terzian found an underrepresentation of female role models and an overrepresentation of males, who are presented more or less as a kind of 'supermen'. Many young people, girls and boys alike, choose stereotyped often aggressive - males as their role models. Eriksen-Terzian's perhaps surprising thesis is that boys are most affected by the sexism that characterizes television output since the culture of aggression these male figures represent can raise doubts in the boys' minds as to their own manliness. There is, in fact, a direct conflict between the values demonstrated by 'macho' media role models and the social training given in most Western European schools, which tries to foster the conviction that girls and boys are equals.

In interviews with twelve English girls between the ages of 16 and 18, Budgeon (1998) explored the relationship between the public figures girls admire and the girls' self-images and outlook on the future. The objects of admiration the girls mention form a broad spectrum, ranging from their own grandmothers to pop stars and authors. One girl said, for example:

The only person I've ever looked up to - I know this sounds stupid - is Sharon Stone or Madonna because they always do whatever they want and go against society and everything, and I'd like to be able to do that (Budgeon 1998:122).

As for their outlook and plans for the future, the girls reject the prospect of the kind of lives their mothers live; at the same time, they look forward to marriage, children and a career.

The girls responses reveal a certain ambivalence. While they are fully aware of the prevailing inequality of men and women in British society, they feel that they, for their parts, as individuals, will be able to break the gender barriers and 'have it all' - husband, family and career. 
We found similar tendencies in our own material, albeit the girls are 3-4 years younger than the girls in the British study:

I: Are there any women you look up to?

R1: Naaah. I know some that really look good, but I don't look up to them. I know this is a bad example, but I think Pamela Anderson is good-looking, but she' just a 'dumb blonde' ... No, sorry about that ... (Another girl is laughing.)

I: What about television series?

R1: No.

I: And you?

R2: No-o-o.

I: How about your mothers?

$\mathrm{R} 1: \mathrm{NO}$

R2: No, the last thing in the world I want to be is like my mother ...working in the Council with handicapped people. I used to fancy teaching riding, but not any more.

I: What's your style?

R1: I'm a poppie, but when I go to parties I'm Techno all the way. I have these amazing electric yellow pants and a little top from Subwear, and my Buffolo shoes.

I: Clothes are important?

R1: Yeah, I think a lot about my looks. I can't stand going around looking crummy.

\section{The Cell Phone - An Umbilical Cord Linking Friends}

Cell phones are assuming a central place in Danish young people's daily lives - especially among adolescents and pre-adolescents. Since cell phones are a relatively new phenomenon, there is hardly any documentation of how children and young people use them.

Junior executives, chiefly young men, were the first to use cell phones, but today children, even very young children, and especially young girls, have taken command of them. They have become a universal accessory, in use everywhere - except for the classroom, where they are explicitly forbidden.

Girls talk on cell phones more than boys, and it would appear that girls use the phones in conversation and through SMS messages to maintain a kind of intimacy in their social relations. In the latter case, SMS users form their own subculture, using codes that few adults can make sense of.

Cell phones allow children to establish a cultural identity of their own; they are particularly impor- tant in establishing and maintaining social relationships. As Danish media researcher Gitte Stald observes:

[The cell phone] is both commonplace and one of the 'necessities' of children's and young people's lives. It has taken its place alongside other media as an integral part of everyday life, playing an important role in children's identity formation, social, cultural and psychological. (Stald 2000:19)

The cell phone is also frequently the topic of discussions about money within the family circle. Many parents try to lay down rules for their children's cell phone use:

Int: What is the family's policy with regard to cell phones?

Mother: [Our daughter] pays the bills herself now, after she ran up a bill of 1000 crowns (135 euro) in a single month. We agreed on an instalment plan.

Int: Who pays her phone card now?

Mother: She gets a card for 100 crowns each month for emptying the dishwasher every day. Int: Is that enough?

Mother: It ought to be. She earns 350 crowns a month doing her own laundry.

Father: Actually, she doesn't spend very much money talking on the phone any more. She uses those SMS messages.

Here, as in many other families, the economic aspect weighs heavy. Parents are unwilling to foot the phone bills their children run up. As a consequence, many families have converted to time-limited phone cards instead of open-ended subscriptions. The problem is more easily dealt with that way.

Thus, we find that initially, the parents have a liberal standpoint, but when the bills reach a certain gravity, their attitude changes. The pattern resembles a pattern noted when young people start to use the Internet. In the beginning parents are all in favour of it - perhaps even a bit proud of how easily their children have learned to find their way around cyberspace. But as the child's surfing habits develop, they change the face of the phone bill. When Peter and Mathilda develop a habit of sitting down in front of the PC after school every day, their parents soon feel a need to impose ceilings and rules.

All in all, we can say the following about girls, boys and the media:

- Some girls and boys have richly diverse media habits whereas others' are more one-sided; the 
patterns covary with the level of formal education in the household.

- Boys and girls use the media differently and have different media preferences. Boys are more interested in computers, and computer games, whereas girls are more interested in media that they can use to establish and maintain social relationships, e.g., chat rooms on the Net and cell phones. Girls are somewhat more interested in music than boys, whereas boys are more interested in sports. The media content girls and boys seek out also differs: girls prefer stories about relationships, whereas boys prefer actionoriented plots.

- Girls and boys approach new media differently, as well. Boys are curious about the technology per se and eager to experiment, whereas girls learn to use new technology when they have perceived its usefulness in enriching their social lives.

- The media play a role in girls' and boys' identity formation and for their self-images, which are expressed in the clothes they wear and in their music tastes. The relationship is both direct, as a media effect, and indirect, inspired by trend-setters in the children's circles of friends.

Many factors contribute to children's development into self-reliant and self-respecting individuals. Their development is the result of the interplay of family norms and values and those of the school, and ideological currents that the children are exposed to in their day-to-day lives as recipients and producers of culture.

\section{Girl Power?}

When girls put on a sexy look, it's because they want to be with it, to be where it's happening. The way they dress is not about sex in the sense of looking for sexual experience, clothes are more a signal of maturity, of fashion-consciousness and selfreliance (Samvirke 12, 2000).

What role do the media play with respect to girls' identity formation and their self-images?

German psychologist Thomas Ziehe has studied young people's identity formation and senses that young people live in a state of ambivalence. On the one hand, they are narcissistic, living in worlds of their own; at the same time, they are eager to find their place in, and to develop personal relationships with, the world around them (Ziehe 2000, 2001).

We can see the same tendencies in our material. We have followed a number of girls and boys from age 12 to age 15 , and it is striking how they developed in terms of personal lifestyle and media habits in that interval. They have gradually become conscious of how they stage themselves and the sources of inspiration they choose with respect to fashion and lifestyle. Since early childhood they have had training in negotiations over one thing or another, with the other children at kindergarten and vis-à-vis adults. They have developed many different competences at an early age. They are, for example, seasoned media consumers and sophisticated strategists in their negotiations with teachers and parents.

And they continue to develop their skills. Girls aged 12-14 today display behaviour that was typical of 15- to 18-year-olds some years ago. Both childhood and adolescence are in flux. Childhood is becoming ever more fleeting; meanwhile, youth is extending over a broader interval, encroaching on childhood and extending well into adulthood. On the one hand, children play (in a traditional sense) a much shorter period than was once the case, and we find some preschoolers dressed like mini-adults. On the other hand, men and women dress and act young well into retirement. Whether you are 8 or 80 , to be attractive is to look as though you were in your twenties. There is reason to suspect that the media have played a part in this development, given their focus on youth as the most attractive period in people's lives.

\section{Am what I Have ...}

New hybrid genres in television like Big Brother are popular among young viewers. Many children know all the figures in the show and seem to identify with their situation, being locked in a room 100 days, and, not least, with their chance of winning a good sum of money. On the whole, we find that money is important, to boys and girls alike. Having money, to be able to afford the things you want, has symbolic value, and it may be that being able to afford the latest fashions has even greater value. Many 13- and 14-year-olds try to find jobs, and if they succeed, they spend their wages on clothes, cell phones, computers and just spending time "on the town". One of our respondents, a girl of 13, earns between 3 and 4,000 crowns each month. She spends it all - on clothes, her hair, and parties. Parents frequently express concern over their children's expensive habits, and the desire for expensive shoes, computer games and so forth truly poses a problem for families of low and moderate incomes. Today's children earn money of their own, and many exert a 
strong influence on their families' behaviour as consumers.

Research indicates a difference between girls and boys with respect to the amount of money they earn. A study conducted by SFI (Socialforskningsinstituttet) in 1999 found that girls aged 13-15 earned an average monthly income of 721 crowns, but boys of the same age earned significantly more, 1,138 crowns a month (Fridberg 1999:31).

Many children start working for pay at age 13, and more recent research indicates that nowadays they earn more. The average income among girls aged 13-18 in 2001 was 1,992 crowns, and among boys 2,278 crowns. Still a difference between the sexes, but the gap has closed (Hansen et al. 2001; Halling \& Tufte 2002).

Once one could reasonably say that children and adolescents were outside the formal economy, that they were dependent on their parents. This presumption is losing its validity. Many older children and young adults now have income of their own, and some at their confirmation in the Lutheran Church (at age 14 in Denmark) receive generous sums of money, which enables them to buy things of symbolic value to them.

\footnotetext{
Int: How do you plan to celebrate your confirmation?

R: I'm not going to be confirmed, but I'm going to have a party. We have rented a place for it. A whole lot of people will be coming. Int: What kind of presents are you hoping for?

R: Lots of money and tons of CDs. My cousin got 10,000 crowns. Wild, isn't it?!! (Girl, 14 years)
}

As for what the young people buy and what they hope to receive in the way of presents, trend-setters in their circle of friends clearly play a major role. It appears that there are always one or two individuals in a circle of friends or school class who set the agenda when it comes to clothes, music, etc. They are the ones who decide what is 'in' and what is not. Those who follow their lead are unwilling to admit that they are under anyone's influence. (It is essentially the same principle as when people children or adults - deny that they have been influenced by advertising, but that they know someone who often is.)

By way of illustration, here are excerpts from two interviews. The first respondent is a girl of 10 who has a monthly allowance of 75 crowns:
Int: How often do you buy new clothes?

R: For my birthday and at Christmas, and then if there's something I really need, like a bathing suit, for example.

Int: Do you have to wear anything special at school?

R: It matters a lot, if you just go around in normal, everyday clothes, things that aren't really expensive or really 'tight', then you're not very popular. Then they just stand there and look at you with a funny expression on their faces.

Int: Who decides what is 'tight'?

R: It's more like what is 'in' and what is 'out'. It just happens. You can see it in ads from H\&M and other shops. I was in Lyngby with a girlfriend to look at clothes. We took the train, and she knew the way. It was a lot of fun.

Another girl, 14 years old, earns her own money and is a trend-setter in relation to the other girls in the class. She says:

I work 3-4 times a week. Fridays I get a
thousand crowns for every 14 days. I use it
on clothes, mostly "Only" from Vero Moda.
Sometimes Mother can use some of my old
clothes; now and then she buys something
for a fifty. I just bought some new shoes in
Skive. I shop for clothes every other week -
sometimes I shop with my mother ... .

Not too many years ago in Denmark boys moved about in the public sphere, while girls spent most of their time talking with their girl friends in their rooms, a so-called 'bedroom culture' (Scott Sørensen 1992). Today we find girls - younger and younger, it seems - on the town shopping, for clothes, CDs, etc. In short, girls are to be seen in the public sphere much more than they used to be: in the real world, in shops and cafés and virtually,'out on the Net'. And they have the money to pay their way. Meanwhile, boys seem to be developing something of a 'bedroom culture' revolving around computer games and video films (Drotner 1999:208f).

\section{Summary}

Some interpret the changes in behaviour among young girls - we are referring to 12- to 14-year-olds - as a sign of "Girl Power". It is a form of 'power' 
that spreads through groups of girls under the influence of one or two dominant individuals. As noted earlier, there seems to be a pattern, whereby trendsetters at school - in combination with other factors, including media content - set the agenda for what 'one' should wear, i.e., what clothes are 'right'. One of our respondents, quoted above, who calls herself a "poppie" and cares a great deal about her looks because she "can't stand going around looking crummy". is a typical trend-setter in her circles, with regard to both clothes and music.

Whether she is "power-full" is open to question. She appears to need to measure her influence in relation to others. When we first visited her, she insisted that her best friend be present in the room. At our last visit - she was now 14 - she was quite preoccupied with her popularity among boys, and looks were very important in this context. Although she may seem 'powerful', certainly verbally so, beneath the surface she is a young girl who is ambivalent and in search of an identity. In her quest she makes use of many resources, including the media, to orient herself about how be - and appear to be - a smart, 'with-it' young woman. The right clothes, the right cell phone and the right leisure accessories are her ticket of admission to the group and confer status.

On the surface, girls - down to the ages of 10-12 - seem to be 'powerful', i.e., confident and competent young women, but behind the façade we find young girls who are as uncertain and searching as young girls always have been. Interestingly, it seems that parents have less to say about girls' con-

\section{References}

Borker, L; Hjarvard, S; Jantzen, C (eds.) (2000) Børn og unges mediebrug [Children's and young people's media use.] Mediekultur, Special issue, August.

Budgeon, S (1998) I'll Tell You What I Really, Really Want: Girl Power and Self-Identity in Britain. In: Inness, S A (ed.) Millennium Girls. Lanham, MD: Rowman \& Littlefield.

Christensen, O \& Tufte, B (2001) Familier $i$ forandring; hverdag og medier $i$ danske familier. [The changing family; media and everyday life in Danish families.] København: Akademisk Forlag.

Dorr, A (1986) Television and Children; A Special Medium for a Special Audience. Beverly Hills/ London/New Delhi: Sage.

Drotner, K (1999) Unge, medier og modernitet: pejlinger $i$ et foranderligt landskab. [Youth, media sumer behaviour than boys', which may be a reflection of the sometimes very strong influence that trend-setters exert over the girls in their class or group. In the ongoing process of internationalization and commercialisation of juvenile culture, it appears that, compared to boys, girls are more impressionable, more sensitive to trends in fashion, music, etc., etc.

What is new these days is that the entertainment and fashion industries appear to have intruded into the family, to have driven a wedge between parents and their children that reaches further and further down to younger and younger girls and boys, an influence that frequently gives rise to debate, not to say friction, between the generations.

Parents and other adults have found it difficult to relate to the signals that the rather young girls are sending. A behaviour, where they are at once sex objects and active, confident young women. But:

As adults who are responsible for our children, we must try to determine whether the strength inherent in 'Girl Power' compensates for its down sides. Reaching a modus vivendi with something like this is no easy task. But it is hardly a reasonable proposition for adults to remain passive and leave something as important as their daughters' transition into adulthood to the entertainment industry. (Dorte Ruge, sociologist specializing in youth, in "Emil", an article on Girl Power in a supplement to Weekendavisen, 29th December 2000.)

and modernity; exploring a changing landscape.] København: Borgen

Drotner, K (2001) Medier for fremtiden: Børn, unge $o g$ det nye medielandskab. [Media for the future: Children, youth and the new media landscape.] København: Høst \& Søn.

Eriksen-Terzian, A (1988) Télévision et sexisme. Cousset (Fribourg): Duval.

Feilitzen C v \& Carlsson, U (eds.)(2000) Children in the New Media Landscape. Göteborg: Göteborg University. (Yearbook of the UNESCO Clearinghouse on Children and Violence on the Screen)

Fridberg, T (1999) 7-15 åriges fritidsaktiviteter. Kultur- og fritidsundersøgelse 1998. [Leisure activities amont 7- to 15-year-olds. Culture and leisure barometer 1998.] København: Socialforskningsinstituttet.

Halling, J \& Tufte, B (2002) The Gender Perspective In Relation to Children as Consumers. Internatio- 
nal Journal of Advertising and Marketing to Children. August.

Hansen, F et al. (2001) Børns opvakst som forbrugere. [Children's socialization as consumers.] København: Samfundslitteratur.

Livingstone, S \& Bovill, M (2001) Children and Their Changing Media Environment. London: Lawrence Erlbaum. (Series: Young People, New Media. London School of Economics and Political Science)

Pecora, N (1999) Children and Television. Communication Research Trends, 19.

Roe, K (1998) Boys Will Be Boys and Girls Will Be Girls. The European Journal of Communication Research, 7.

Ruge, D (2000) Emil. Weekendavisen, 29. december (Supplement).
Samvirke (2000) no. 12

Scott Sørensen, A (1992) Kønnets kultur; om unge og ungdom. [The culture of gender; about young people and being young.] Tidsskrift for børne- og ungdomsmedier, 23 (juni).

Stald, G (2000) Telefonitis: unge danskeres brug av telefonen i IT-tidsalderen. [Telephonitis; young Danes' use of the telephone in the age of IT.] Mediekultur. August, Special issue.

Ziehe, T (2000) School \& Youth - A Differential Relation; Reflections on Some Blank Areas in the Current Reform Discussions. Young, 8.

Ziehe, T (2001) De personlige livsverdeners dominans. [The dominance of personal values.] Uddannelse, 10 . 